\title{
Aortic Augmentation Pressure
}

National Cancer Institute

\section{Source}

National Cancer Institute. Aortic Augmentation Pressure. NCI Thesaurus. Code C122084.

The calculated difference between the second and first aortic systolic peaks, which is an indirect measure of arterial stiffness. 